\title{
Grafting methods and use of fasteners in monoembryonic, polyembryonic, and multi-stemmed jaboticaba (Plinia jaboticaba (Vell) Berg) seedlings
}

\author{
Julcinara Oliveira Baptista*® ${ }^{\circledR}$, José Carlos Lopes ${ }^{\circledR}$, Edilson Romais Schmildt` \\ Caroline Palacio de Araujo ${ }^{(D)}$, Rodrigo Sobreira Alexandre ${ }^{(1)}$ \\ Federal University of Espírito Santo \\ *Corresponding author, e-mail: julcinarabaptista@hotmail.com
}

\begin{abstract}
Jaboticaba is a native fruit from Brazil, appreciated for its sweet taste and organoleptic characteristics. The propagation of this fruit species occurs exclusively through seeds, which present high germination rates, although with a long period of juvenility, a fact that favors advances in studies aiming at an early fruiting. This research aimed to study a more adequate and rapid grafting method for the jaboticaba cv. Sabará. The experimental design was in randomized blocks, with 12 treatments consisting of combinations using three types of seedlings (monoembryonic, polyembryonic, and multi-stemmed), two grafting methods (top cleft and splice grafting), and two fasteners (parafilm ${ }^{\oplus}$ tape and circular clip), with three replications consisting of 10 seedlings each. The analyzed characteristics were: monoembryony (\%); polyembryony (\%), multi-stemming (\%), grafting success rate (\%), survival (\%), scion length $(\mathrm{cm})$, scion diameter $(\mathrm{mm})$, and rootstock diameter $(\mathrm{mm})$. The percentage of monoembryony (46.4\%) was higher than the success rates of polyembryony (36\%), and multi-stemming (17.6\%). The top cleft grafting method of monoembryonic seedlings fastened with parafilm ${ }^{\circledast}$ and circular clip, and polyembryonic seedlings fastened with circular clip were the more suitable for grafting in the jaboticaba cv. Sabará.
\end{abstract}

Keywords: Plinia sp., living grafts, vegetative propagation, compatibility

The jaboticaba tree (Plinia jaboticaba (Vell) Berg) is one of the most cultivated plant species native to Brazil, and its fruits stand out as one of the most consumed by Brazilian families due to their sweet taste. In addition to the high soluble solids content of fruits and their derivatives, they are also rich in phenolic compounds, important for human health due to their antioxidant and anticarcinogenic properties (Leite-Legatti et al., 2012).

The primary propagation method for the jaboticaba tree is still by seeds, a method that demands from 8 to 15 years after planting for the beginning of production. In this perspective, advances in the use of vegetative propagation methods are necessary to anticipate production. In this context, grafting is considered a highly efficient method in the production of jaboticaba seedlings, since it maintains the characteristics of the mother plant and provides early fruiting (Sasso et al., 2010). Besides, grafting offers more advantages than other vegetative propagation techniques for the jaboticaba tree, such as cuttings and air layering, since the species presents a difficult rooting, requiring the use of growth regulators that render the process costly. When grafted, the jaboticaba seedlings start the fruiting period after four years of planting (Silva et al., 2019).

Among the important propagation characteristics are polyembryony and multi-stemming. The first refers to the case when there is more than one embryo per seed, resulting in more seedlings in individuals with low vegetative propagation (Alexandre et al., 2010; Silva et al., 2019). However, in multi-stemmed seedlings, the main stems can initially function as a propagation source for grafting, whereas the adjacent stem represents a source of photoassimilates for the grafted region. For avocado, studies have shown that allometric growth is directly related to increased nutrition and shoot growth, therefore increasing the photosynthetic area and the storage of photoassimilates required for growth (Paixão et al., 2016).

The success of grafting is the result of the complete junction between scion and rootstock. High attachment rates depend on conditions of material uniformity, adequate thickness, tissue lignification, and the type of fasteners present in the graft (Schmildt et al., 
2018). Also, graft growth is mainly influenced by good vascular connection. Therefore, the greater is the tissue connection between scion and rootstock, the greater is the growth of the graft, forming vigorous seedlings (Melo et al., 2017).

This work aimed to study a faster and more adequate grafting method and the fasteners for monoembryonic, polyembryonic, and multi-stemmed seedlings, as well as to verify which type of seedling is suitable for grafting in the jaboticaba tree.

The study was developed in the Laboratory of Forest Seeds (LSF) and in the Plant Nursery of the Forestry and Wood Science Department (DCFM) of the Center of Agricultural Sciences and Engineering (CCAE), belonging to the Federal University of Espírito Santo (UFES), municipality of Jerônimo Monteiro, Espírito Santo state, Brazil.

The experimental design was in randomized blocks, with 12 treatments consisting of combinations of three types of seedlings (monoembryonic, polyembryonic, and multi-stemmed), two grafting methods (top cleft and splice grafting), and two fasteners (parafilm ${ }^{\circledR}$ tape and circular clip), with three replications consisting of 10 seedlings each.

Ripe fruits of the jaboticaba cv. Sabará were harvested from individuals of an orchard located in the municipality of Jerônimo Monteiro - ES and immediately taken to the Laboratory of Forest Seeds. The seeds were then extracted and rubbed with quicklime against a tray sieve with a stainless-steel mesh to remove the mucilage. Subsequently, the seeds were sown into $290 \mathrm{~cm}^{3}$ tubes filled with the bioplant ${ }^{\circledR}$ substrate; part of the tubes was kept in the plant nursery, while another part was employed in the formation of four 250-seed lots, where the monoembryonic, polyembryonic, and multi-stemmed seedlings were registered. Afterward, the seedlings were transplanted into $15 \times 29 \times 7 \mathrm{~cm}$ plastic bags and, after three months, the polyembryonic seedlings were pruned, maintaining two seedlings per seed.

Grafting was performed six months after seed germination. The scions were originated from adult mother plants and were approximately $10 \mathrm{~cm}$ long. In the splice grafting, the scion and rootstock were excised in a single bevel, with opposite cuts performed with the aid of a stainless-steel blade. In the top cleft grafting, a longitudinal cut approximately $1 \mathrm{~cm}$ long was performed in the rootstock and a " $\mathrm{V}$ " shaped double bevel cut was performed in the scion. The insertion into the longitudinal slit was performed so that one of the scion sides matched the rootstock side.
The graft wrapping was made using two fasteners: parafilm ${ }^{\circledR}$ and a circular clip. The parafilm ${ }^{\circledR}$ tape was wrapped in the grafting region, whereas the circular clip was placed in the excised region and the shoots above the grafted region were wrapped with a plastic bag, forming a moist chamber. The irrigation of the grafted plants was performed daily with $100 \mathrm{~mL}$ of water.

The analyses of monoembryony (\%), polyembryony (\%), multi-stemming (\%), grafting success rate (\%), survival (\%), scion length $(\mathrm{cm})$, scion diameter $(\mathrm{mm})$, and rootstock diameter $(\mathrm{mm})$ were evaluated after 60 days of grafting. The high-resolution scanning of longitudinal sections of the grafted region was performed for treatments 2 and 6, using a 4800-dpi resolution. The data found in this work were subjected to the Scott-Knot grouping test at a $5 \%$ level of significance, using the Genes computer software (Cruz, 2016).

This is the first work with this species that jointly analyzed monoembryony, polyembryony, and multistemming. This work even reports the difference between polyembryonic and multi-stemmed seedlings, so as not to make evaluation errors.

The percentage of monoembryonic, polyembryonic, and multi-stemmed seedlings was $46.4 \%, 36 \%$, and $17.6 \%$, respectively. This suggests that the jaboticaba cv. Sabará presents low polyembryony when compared to the results obtained by Gurgel \& Sobrinho (1951) who, after investigating Plinia cauliflora and Plinia trunciflora, determined three classifications for the degree of polyembryony: high (greater than 70\%), medium (between 40 and 70\%), and low (less than $40 \%$ ). The jaboticaba cv. Sabará presented a low polyembryony rate, which is related to seed size. Upon evaluation of two jaboticaba cultivars, cv. Sabará and cv. Cabinho, Wagner Júnior et al. (2011) showed that the species and the seed size influenced the number of seedlings per seed. The jaboticaba cv. Sabará presented a higher number of seedlings per seed (1.46) compared to the cv. Cabinho (1.29). The authors also observed that the seed diameters, $<6 \mathrm{~mm}$ (1.13), 6-8 mm (1.49), and >8 $\mathrm{mm}(1.53)$ resulted in a higher number of seedlings. This may explain why monoembryonic seedlings occurred in a higher percentage (46.4\%), whereas multi-stemmed seedlings were present in a lower percentage (17.6\%), possibly because they were originated from smaller seeds, with limited nutrient storage. Therefore, although both monoembryonic and multi-stemmed seedlings presented one embryo per seed, the latter originated multiple stems from a single embryonic axis. 
The highest success rates in the grafting of the jaboticaba cv. Sabará were 13.33\% (monoembryonic + top cleft grafting + circular clip), $26.66 \%$ (monoembryonic + top cleft grafting + parafilm ${ }^{\circledR}$ ), and $20.0 \%$ (polyembryonic + top cleft grafting + circular clip) (Table 1), using 8-monthold rootstocks with a diameter of approximately $4 \mathrm{~mm}$. These results are above those by Cassol et al. (2017), who obtained a grafting success rate of $20.38 \%$ using 2 to 3 -year old rootstocks with a diameter of approximately $6 \mathrm{~mm}$. The results of the present work are favorable since the seedlings were grafted early, with a 16 to 28 -month difference, that is, a shorter production time of 2 or 3.5 fold.

Table 1. Graft-take percentage (GTP), survival percentage (SP), graft length (GL), graft diameter (GD), rootstock diameter (RD), and diameter of the grafted region (DGR) of seedlings of the jabuticaba cv. Sabará.

\begin{tabular}{|c|c|c|c|c|c|c|}
\hline Treatments & GTP(\%) & SP(\%) & $\mathrm{GL}(\mathrm{cm})$ & $\mathrm{GD}(\mathrm{mm})$ & $\mathrm{RD}(\mathrm{mm})$ & $\mathrm{DRD}(\mathrm{mm})$ \\
\hline 1 & $13.33 a^{(1)}$ & $13.33 a$ & $7.86 a$ & $1.21 \mathrm{a}$ & $1.47 \mathrm{a}$ & $2.04 a$ \\
\hline 2 & $26.66 \mathrm{a}$ & $26.66 \mathrm{a}$ & $7.83 a$ & $0.91 \mathrm{a}$ & $1.13 a$ & $1.26 \mathrm{a}$ \\
\hline 3 & $0.00 \mathrm{~b}$ & $0.00 \mathrm{~b}$ & $0.00 \mathrm{~b}$ & $0.00 a$ & $0.00 a$ & $0.00 a$ \\
\hline 4 & $0.00 \mathrm{~b}$ & $0.00 \mathrm{~b}$ & $0.00 \mathrm{~b}$ & $0.00 a$ & $0.00 a$ & $0.00 a$ \\
\hline 5 & $20.00 a$ & $20.00 \mathrm{a}$ & $7.93 a$ & $1.08 \mathrm{a}$ & $1.34 \mathrm{a}$ & $1.84 \mathrm{a}$ \\
\hline 6 & $6.66 \mathrm{~b}$ & $6.66 \mathrm{~b}$ & $3.73 \mathrm{~b}$ & $0.61 a$ & $0.72 a$ & $0.96 a$ \\
\hline 7 & $6.66 \mathrm{~b}$ & $6.66 \mathrm{~b}$ & $2.70 \mathrm{~b}$ & $0.51 a$ & $0.62 a$ & $0.84 a$ \\
\hline 8 & $0.00 \mathrm{~b}$ & $0.00 \mathrm{~b}$ & $0.00 \mathrm{~b}$ & $0.00 \mathrm{a}$ & $0.00 a$ & $0.00 \mathrm{a}$ \\
\hline 9 & $0.00 \mathrm{~b}$ & $0.00 \mathrm{~b}$ & $0.00 \mathrm{~b}$ & $0.00 a$ & $0.00 a$ & $0.00 a$ \\
\hline 10 & $6.66 \mathrm{~b}$ & $6.66 \mathrm{~b}$ & $3.03 \mathrm{~b}$ & $0.39 a$ & $0.45 a$ & $0.71 \mathrm{a}$ \\
\hline 11 & $0.00 \mathrm{~b}$ & $0.00 \mathrm{~b}$ & $0.00 \mathrm{~b}$ & $0.00 a$ & $0.00 a$ & $0.00 a$ \\
\hline 12 & $0.00 \mathrm{~b}$ & $0.00 \mathrm{~b}$ & $0.00 \mathrm{~b}$ & $0.00 a$ & $0.00 a$ & $0.00 a$ \\
\hline $\begin{array}{l}\text { "Means followed } \\
+ \text { c circular clip; } 2 . n \\
+ \text { splice grafting } \\
\text { polyembryonic + } \\
\text { circular clip; } 10 . n \\
\text { splice grafting + }\end{array}$ & $\begin{array}{l}\text { film: } 5 \text {. pol } \\
\text { grafting + } \\
\text { emmed }+\end{array}$ & $\begin{array}{l}\text { of significa } \\
\text { ft grafting } \\
\text { onic + top } \\
\text { clip; } 8 \text {. po } \\
\text { grafting + }\end{array}$ & $\begin{array}{l}\text { ent }(P \leq 0 . c \\
m^{\oplus ;} ; 3 . \text { mon } \\
\text { afting + cir } \\
\text { onic + splic }\end{array}$ & $\begin{array}{l}\text { Knott). Les } \\
\text { nic + splic } \\
\text {; } 6 \text {. polyer } \\
\text { g + parafi } \\
d+\text { splice }\end{array}$ & $\begin{array}{l}\text { Tonoembry } \\
\text { + circular } \\
\text { + top cleft } \\
\text { ulti-stemme } \\
\text { + circular cli }\end{array}$ & $\begin{array}{l}\text { op cleft grafti } \\
\text { nonoembryor } \\
\text { g + parafilm }{ }^{\oplus} \text {; } \\
\text { cleft grafting } \\
\text { nulti-stemmed }\end{array}$ \\
\hline
\end{tabular}

The most suitable graft modality for the jaboticaba cv. Sabará was the top cleft grafting, through which it obtained the highest set rates, namely 13.33; 20.00, and $26.66 \%$ respectively (Table 1 ). Conversely, studies evaluating the modalities of top cleft and splice grafting for the jaboticaba cv. Sabará and jaboticaba cv. Açu, using monoembryonic seedlings, verified that for the cv. Sabará the splice grafting modality $(96.88 \%)$ was superior to the top cleft grafting (68.75\%) and for the cV. Açu, both modalities presented an attachment percentage of $93.75 \%$, not statistically different from each other, also presenting a greater mean of attachment percentage. In addition, the final rod length for the cv. Sabará was $16.18 \mathrm{~cm}$, using a rootstock with approximately $6 \mathrm{~mm}$ of diameter. The topdressing fertilization was performed after 70 days, with a subsequent stem growth evaluation at 262 days after grafting (Franco et al., 2010). In the present study, length evaluations were performed 60 days after grafting, in which the highest graft growth values were also found in the highest attachment percentage, 7.86; 7.83 , and $7.93 \mathrm{~cm}$ (Table 1), showing that even with lower attachment percentages there was gain in days, compared to stem growth, of approximately 200 days.

In the jaboticaba plant, grafting failure is verified in longitudinal sections of the grafted region in the form of dried brown-colored tissues (Figure 11), whereas successful grafts, obtained through the top cleft grafting of monoembryonic seedlings fastened with parafilm ${ }^{\circledR}$ exhibited a perfect union, verified in the greenish coloring of tissues and callouses (Figure 1k, arrow). One of the explanations is that the parafilm ${ }^{\circledR}$ grafting tape promotes the sealing of the grafted region, preventing the dryness of the tissues.

The superior performance of the parafilm ${ }^{\circledR}$ fastener over the circular clip may be justified by the fact that the first is malleable and fits evenly into the grafted region, providing a perfect fit for the grafted parts. The circular clip, on the other hand, does not fully surround the grafted region and is easier to detach from the site, leading to a misalignment of the grafted parts (Oliari et al., 2016). There was a significant difference in scion growth in terms of the grafting methods used in the study, in which the splice grafting led to lower scion growth $(2.70$ $\mathrm{cm})$, whereas the top cleft grafting caused the highest growth $(7.93 \mathrm{~cm})$, with the treatments that provided the highest scion growth also providing the highest grafting success rates (T1, T2, and T5) (Table 1). A probable explanation for this growth pattern is related to the larger diameters of the scions, since according to Gomes et al. (2010) these may present higher nutrient storage content, which can favor the rapid cellular differentiation and the greater rapidity of callus formation, being responsible 
for the success of the union and the greater growth of the grafted seedlings. Larger diameters of the scion, rootstock, and grafted region were also observed in $\mathrm{T} 1$, T2, and T5 (Table 1). This reduced growth may also be related to the difference in graft and rootstock thickness, causing poor connection of the conducting vessels, thus hindering nutrient translocation. This behavior was observed in the grafting of guava trees resistant to Meloidogyne enterolobii, in which an incompatibility between the combination of Psidium guajava $\mathrm{cv}$. Paluma and Psidium cattleyanum L. was verified, resulting in low seedling vigor in the field due to the difference in thickness, with the largest thickness observed in the grafted plants (Robaina et al., 2015). Treatments T2 and T6 represent the top cleft grafting method and Parafilm ${ }^{\circledR}$ grafting tape as a fastener. In relation to T2, T6 provided low compatibility between scion and rootstock (Figure 1k and I). This unsuccessful result may be associated with the use of polyembryonic seedlings in T6, which may lead to water and nutrient competition between the two stems. Another possible reason relies on the small scion (0.61) and rootstock (0.72) diameters, and the presence of an adjacent stem compared to $\mathrm{T} 2$, making it difficult to manage the parts to be grafted, possibly due to delayed sealing and decreased tissue joint as a consequence of water loss. The use of multi-stemmed seedlings grafted into one of the stems was not efficient as it provided low survival $(6.66 \%)$ (Table 1), which may be justified by the ungrafted stem requiring large amounts of water for the production of photoassimilates.

It was concluded that the most suitable graft modality for the jaboticaba cv. Sabará is the fork on the top in a full slit, using seedlings produced from monoembryonic seeds, fastened with Parafilm ${ }^{\circledR}$.

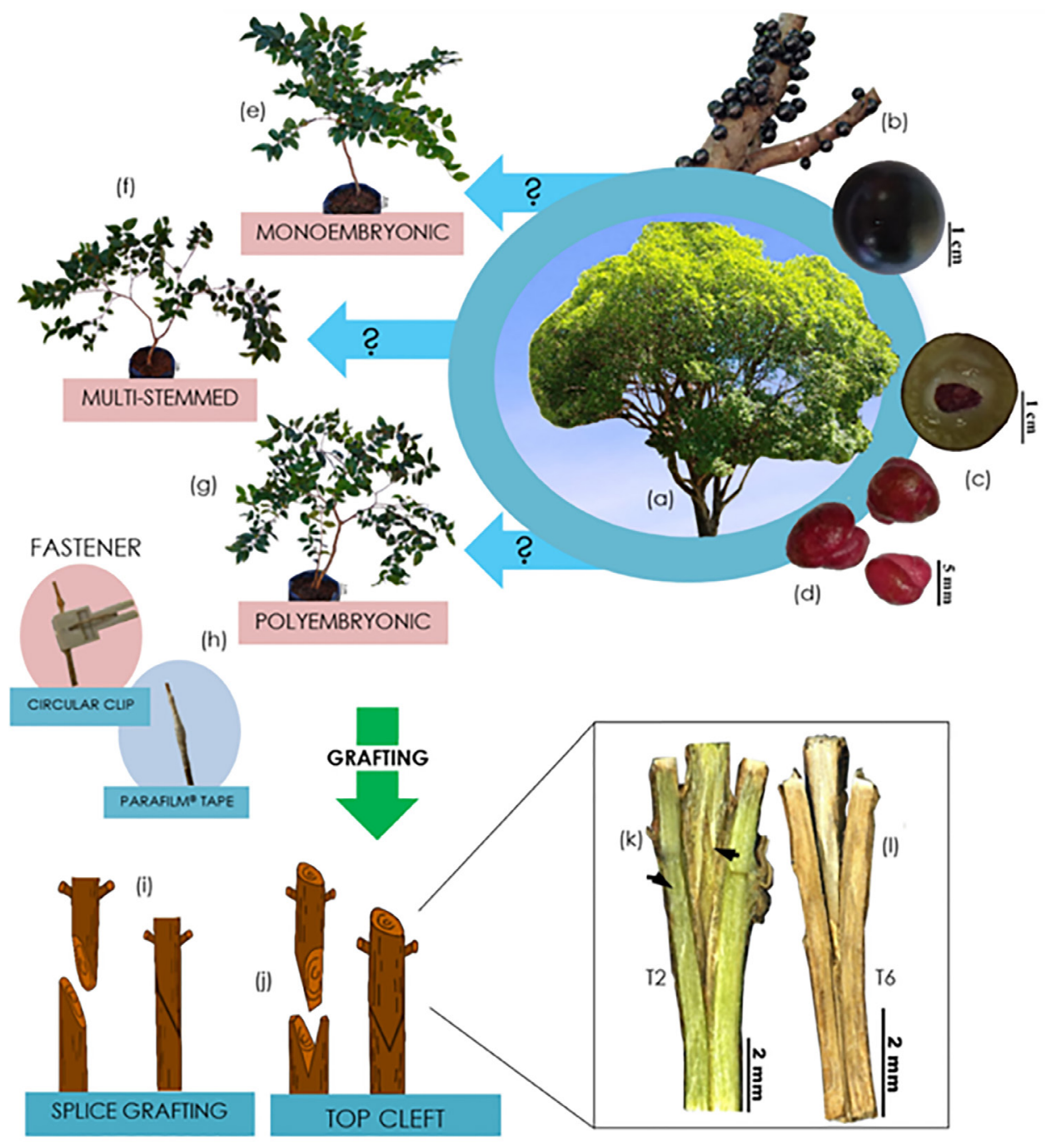

Figure 1. Mother tree (a); fruit (b); broken fruit showing liquid endosperm and seed (c); isolated seeds (source of genetic diversity) (d); monoembryonic seedling (e); multi-stemmed seedling (f); polyembryonic seedling (g); parafilm ${ }^{\circledast}$ fasteners and circular clip (h); splice grafting (i); fork in the top in full slit (j); compatibility (k); and incompatibility (I) between scion and rootstock in the top cleft method. 


\section{References}

Alexandre, R.S., WagnerJúnior, A., Negreiros, J.R.S., Bruckner, C.H., Lopes, J.C., Dias, M.A. 2010. Seed germination and emergency of two Myrciaria in thre substrates. Acta Horticulturae 864:175-179.

Cassol, D.A., Pirola, K., Dotto, M., Citadin, I., Mazaro, S.M., Wagner Junior, A. 2017. Grafting technique and rootstock species for the propagation of Plinia cauliflora. Ciência Rural 47: 1-6.

Cruz, C.D. 2016. Genes Software - extended and integrated with the R, Matlab and Selegen. Acta Scientiarum. Agronomy 38: 547-552.

Franco, L.R.L., Silva, J.F., Maia, V.M., Lopes, P.S., Amorim, I.J.F., Mizobutsi, E.H. 2010. Pegamento e crescimento inicial de mudas de jabuticabeiras 'Açu' e 'Sabará' submetidas a dois tipos de enxertia. Revista Ceres 57: 535-538.

Gomes, W.A., Mendonça, R.M.N., Souza, E.P., Estrela, M.A., Melo, V.S., Silva, S.M., Souza, A.P. 2010. Garfagem e diâmetro de porta-enxerto na obtenção de mudas de umbuzeiro do acesso laranja. Revista Brasileira de Fruticultura 32: 952-959.

Gurgel, J.T. A., Sobrinho, J. 1951. Poliembrionia em mirtáceas frutíferas. Bragantia 11: 4-6.

Leite-Legatti, A.V., Batista, A.G., Dragano, N.R.V. Marques, A.C., Malta, L.G., Riccio, M.F., Eberlin, M.N., Machado, A.R.T., Silva, L.B.C., Ruiz, A.L.T.G., Carvalho, J.E., Pastore, G.M., Marostica Júnior, M.R. 2012. Jaboticaba peel: Antioxidant compounds, antiproliferative and antimutagenic activities. Food Research International 49: 596-603.

Melo, E.T., Pio, R., Balbi, R.V., Ferreira, C.A., Mori, F.A. 2017. Anatomic compatibility of pear and quince trees grafted on Pyrus calleryana and Chaenomeles sinensis rootstocks. Pesquisa Agropecuária Brasileira 52: 877-886.

Oliari, L.S., Giles, J.A.D., Mayrinck, L.G., Oliveira, J.P.B., Lopes, J.C., Otoni, W.C., Schmildt, E.R., Aoyama, E.M., Alexandre, R.S. 2016. Mini-grafting of adult Passiflora edulis Sims f. flavicarpa Deg. scions onto vegetatively propagated adult rootstocks of $P$. mucronata Lam. Australian Journal of Crop Science 10: 490-496.

Paixão, M.V.S., Lopes, J.C., Schmildt, E.R., Alexandre, R.S., Meneghelli, C.M. 2016. Avocado seedlings multiple stems production. Revista Brasileira de Fruticultura 38:1-7.

Robaina, R.R., Campos, G.S., Marinho, C.S., Souza, R.M., Bremenkamp, C.A. 2015. Grafting guava on cattley guava resistant to Meloidogyne enterolobii. Ciência Rural 45: 1579-1584.

Sasso, S.A.Z., Citadin, I., Danner, M.A. 2010. Propagação de jabuticabeira por estaquia. Revista Brasileira de Fruticultura 32: 577-583.

Schmildt, E.R., Oliari, L.S., Alexandre, R.S., Silva, F.O.R., Schmildt, O. 2018. Histological aspects of mini-grafting of passiflora edulis sims. And passiflora mucronata lam.
Revista Brasileira de Fruticultura 40: (e-174).

Silva, J.A.A., Teixeira, G.H.A., Martins, A.B.G., Citadin, I., Wagner Júnior, A., Danner, M.A. 2019. Advances in the propagation of Jabuticaba tree. Revista Brasileira Fruticultura 41: (e-024).

Wagner Júnior, A., Silva, J.O.C., Pimentel, L.D., Santos, C.E.M., Bruckner, C.H. 2011. Germinação e desenvolvimento inicial de duas espécies de jabuticabeira em função do tamanho de sementes. Acta Scientiarum. Agronomy 33: 105-109.

Conflict of Interest Statement: The authors declare that the research was conducted in the absence of any commercial or financial relationships that could be construed as a potential conflict of interest.

All the contents of this journal, except where otherwise noted, is licensed under a Creative Commons Attribution License attribuition-type BY. 